Short communication

\title{
Influence of age, sex and breeding status on mercury accumulation patterns in the wandering albatross Diomedea exulans
}

\author{
S. Tavares ${ }^{\mathrm{a}, *}$, J.C. Xavier ${ }^{\mathrm{b}, \mathrm{c}}$, R.A. Phillips ${ }^{\mathrm{b}}$, M.E. Pereira ${ }^{\mathrm{d}}$, M.A. Pardal ${ }^{\mathrm{a}}$ \\ ${ }^{a}$ CFE (Centre for Functional Ecology), Department of Life Sciences, University of Coimbra, PO Box 3046, 3001-401 Coimbra, Portugal \\ ${ }^{\mathrm{b}}$ British Antarctic Survey, Natural Environment Research Council, High Cross, Madingley Road, Cambridge, CB3 OET, UK \\ ' IMAR (Institute of Marine Research), Department of Life Sciences, University of Coimbra, 3004-517 Coimbra, Portugal \\ ${ }^{\mathrm{d}}$ CESAM (Centre for Environmental and Marine Studies), Department of Chemistry, University of Aveiro, 3810-193 Aveiro, Portugal
}

\section{A R T I C L E I N F O}

\section{Article history:}

Received 4 March 2013

Received in revised form

21 June 2013

Accepted 23 June 2013

\section{Keywords:}

Trace metals

Pollution

Bioaccumulation

Seabird

\begin{abstract}
A B S T R A C T
Although mercury bio-amplifies through the food chain and accumulates in top predators, mercury concentrations in tissues of the wandering albatross are greater than in any other vertebrate, including closely related species. In order to explore the alternative explanations for this pattern, we measured total mercury concentrations in feathers, plasma and blood cells of wandering albatrosses of known age, sex and breeding status sampled at South Georgia. Mercury concentrations were low in feathers and blood components of chicks, and higher in the feathers of young pre-breeders than in feathers or blood of older pre-breeders and breeding adults. There was no effect of sex on mercury concentrations in the feathers of pre-breeders or breeding adults, whereas levels were significantly higher in blood cells of breeding females than males. The high feather mercury concentrations of young pre-breeders compared with older birds suggest an increase in moult frequency as birds approach maturity.
\end{abstract}

(c) 2013 Elsevier Ltd. All rights reserved.

\section{Introduction}

Marine ecosystems provide crucial resources and services for humans, but have been greatly altered by the effects of fisheries, climate change and release of hazardous contaminants (Halpern et al., 2008). Given its toxicity and tendency to bioaccumulate, contamination by mercury $(\mathrm{Hg})$ is a major concern for environmental agencies and policy makers. Mercury also biomagnifies through the food web, concentrating in the tissues of top predators, including marine and freshwater fish, which raises human health issues (EPA, 2001)

Marine top predators are widely regarded as effective monitors of ocean health because they integrate processes occurring at lower trophic levels (Monteiro and Furness, 1995). Also, given their large foraging ranges, levels of pollutants in their tissues reflect those of a wide area, including potentially remote regions that would otherwise be difficult to sample (Thompson et al., 1993; Stewart et al., 1999; Blévin et al., 2013). Moreover, their distributions change seasonally (Phillips et al., 2008), permitting a comparison between pollutant levels in breeding and nonbreeding areas (Ramos and González-Solís, 2012).

\footnotetext{
* Corresponding author.

E-mail address: stavares@student.uc.pt (S. Tavares).
}

Antarctica is considered to be one of the most undisturbed areas of the world. However, mercury is widely distributed as a consequence of long-range atmospheric transport, and wet and dry deposition processes, and some of the highest organic mercury concentrations observed in the open ocean were recorded in Antarctic waters (Cossa et al., 2011). Mercury emissions are predicted to increase (Streets et al., 2009), raising concern about impact on these remote areas. Previous studies have highlighted an increase in mercury contamination of several seabird species from South Georgia and New Zealand over the last few decades (Thompson et al., 1993; Becker et al., 2002).

The wandering albatross, Diomedea exulans, is a wide-ranging top predator, and its mercury concentrations reflect contamination over a huge foraging area that encompasses Antarctic, subantarctic and subtropical waters. Mercury levels measured previously in this species were much higher than in related taxa with similar diets from the same localities (Thompson et al., 1993; Hindell et al., 1999; Stewart et al., 1999; Anderson et al., 2009). Even more surprising is that these values exceed those in seabirds in the Northern Hemisphere (e.g. Doi et al., 1984; Monteiro and Furness, 1995; Stewart et al., 1997; Bearhop et al., 2000).

Although several studies have measured mercury levels in albatrosses (Thompson et al., 1993; Hindell et al., 1999; Stewart et al., 1999; Becker et al., 2002; Anderson et al., 2009; Blévin et al., 2013), none included data from birds ranging in age from chicks to adults, 
despite the potential for elucidating the key factors contributing to lifetime mercury accumulation. In this study, we measured total mercury concentration in feathers of chicks, young and old prebreeders, and in feathers, blood cells and plasma of breeding adults, all of known-age, in the wandering albatross at South Georgia. Mercury in feathers is considered to be a reliable measure of total body burden at the time of feather formation (Monteiro and Furness, 2001). This is because mercury is sequestered in the sulfhydryl groups of keratin, so concentrations reflect the uptake and storage of mercury between moults (Ochoa-acuña et al., 2002). Mercury bound in the plumage can account for up to $93 \%$ of the accumulated body burden (Braune and Gaskin, 1987). In adult wandering albatrosses, feather replacement takes place exclusively during the nonbreeding period (Weimerskirch, 1991). In chicks, two generations of feathers are grown post-hatching, an initial down and later pennaceous (or 'true') feathers. Down sampled early in development may include a residual signal of the maternal mercury burden via the egg, but this is likely to be diluted quickly, as the rate of plumage growth in procellariiform chicks is rapid (Phillips and Hamer, 2000). The utility of analysing mercury concentrations in blood is that these largely reflect accumulation from the time of the previous moult, less any mercury that has been demethylated from its more toxic methyl, to less toxic inorganic form and potentially sequestered in internal tissues (Thompson and Furness, 1989) or, in females, was deposited in the egg (Lewis et al., 1993). Hence our sampling programme allowed us to determine mercury dynamics in relation to age, sex and breeding status, and to determine the key factors underpinning long-term mercury accumulation.

\section{Methodology}

Fieldwork was undertaken on Bird Island, South Georgia ( $54^{\circ} 00^{\prime} \mathrm{S}, 38^{\circ} 03^{\prime} \mathrm{W}$ ). Between January 2005 and February 2010, 6-8 body feathers (selected at random) were obtained from 20 returning pre-breeders visiting the colony in the earlymidsummer; 7 were young pre-breeders ( $4-6$ years) and 13 were old prebreeders (9-15 years). In May-October 2009, blood samples ( $1 \mathrm{ml}$ blood from the tarsal vein) and body feathers were collected from 6 breeding adults, also of known age, each month. Down and blood were also sampled in 4 chicks in May and September 2009. Feathers were stored dried, and blood was separated into plasma and cells using a centrifuge (15 min at $3000 \mathrm{rpm}$ ) and stored frozen within $2 \mathrm{~h}$ of collection. No bird was sampled more than once, nor a sample taken from both members of any pair. Birds were sexed using plumage and morphology (Tickell, 1968), and all had been ringed as chicks and so were of known age.

Feathers were cleaned with a chloroform and diethyl ether solution (2:1) and dried at $50^{\circ} \mathrm{C}$ prior to analysis. Repeatability in mercury measurement was assessed using paired feather samples from the same individuals. Samples of both plasma and blood cells were subsequently freeze-dried and homogenized, and total mercury determinations of samples of $0.20-7.62 \mathrm{mg}$ was performed by thermal decomposition atomic absorption spectrometry with gold amalgamation, using a LECO AMA254. Accuracy and precision were assured by the daily analysis of a certified reference material (CRM) of similar matrix to the samples (TORT-2), obtained from the National Research Council of Canada. The results for the CRM were always within the certified value $\left(0.27 \pm 0.06 \mathrm{mg} \mathrm{kg}^{-1}\right)$ with a recovery efficiency of $102.8 \pm 7.85 \%(n=49)$. The results were corrected for the daily recovery percentage of the CRM analyses.

After checking for normality, data were analysed using parametric procedures after logarithmic transformation of mercury concentrations. ANOVAs were used to evaluate the effects of age, sex and breeding status on tissue Hg concentrations, followed by unequal $\mathrm{N}$ Tukey HSD post-hoc test (given the unequal group sizes). Pearson correlations or ANCOVA were used to assess relationships between mercury concentrations, age and sex. Differences in mercury levels between chicks and breeding adults were examined using unpaired $t$-tests. Consistency in mercury levels measured in two different feathers sampled from the same individual was examined using intraclass correlation. Significant levels were set at $p<0.05$.

Table 1

Review of the published data on the Hg levels in a number of albatrosses species (mean \pm SD in mg kg ${ }^{-1} \mathrm{dry}_{\mathrm{wt}}$ ).

\begin{tabular}{|c|c|c|c|c|c|c|c|}
\hline Species & & Location & Feathers & Blood & Liver & $n$ & Source \\
\hline \multirow[t]{6}{*}{ Diomedea exulans } & Wandering & South Georgia & $20.1 \pm 7.6$ & $9.6 \pm 4.3$ & & 31 & Present study \\
\hline & albatross & & $19.6 \pm 10.1$ & & & 66 & Thompson et al. (1993) \\
\hline & & & $27.4 \pm 8.1$ & $11.2 \pm 3.4$ & & 14 & Anderson et al. (2009) \\
\hline & & Marion Island & $24.8 \pm 12.4$ & & & 29 & Thompson et al. (1993) \\
\hline & & New Zealand & & & $360.0 \pm 183.0$ & 9 & Stewart et al. (1999) \\
\hline & & $\begin{array}{l}\text { Southern Pacific and } \\
\text { Indian Oceans }\end{array}$ & & & $482.3 \pm 120.7$ & 22 & Hindell et al. (1999) \\
\hline \multirow[t]{2}{*}{ Diomedea dabbenena } & Tristan albatross & Gough Island & $28.0 \pm 14.3$ & & & 27 & Thompson et al. (1993) \\
\hline & & & & & $1343 \pm U$ & 2 & $\begin{array}{l}\text { Thompson and Furness } \\
\text { (1989) }\end{array}$ \\
\hline \multirow[t]{3}{*}{ Diomedea epomophora } & Royal albatross & New Zealand & $11.5 \pm 13.9$ & & & 22 & Thompson et al. (1993) \\
\hline & & & & & $449.3 \pm 490.1$ & 4 & Stewart et al. (1999) \\
\hline & & $\begin{array}{l}\text { Southern Pacific and } \\
\text { Indian Oceans }\end{array}$ & & & $108.6 \pm 35.8$ & 9 & Hindell et al. (1999) \\
\hline \multirow[t]{5}{*}{ Thalassarche melanophris } & Black-browed & South Georgia & $4.6 \pm 1.9$ & & & 20 & Thompson et al. (1993) \\
\hline & albatross & & $5.4 \pm 2.0$ & & & 16 & Becker et al. (2002) \\
\hline & & & $8.3 \pm 2.6$ & $4.4 \pm 1.1$ & & 16 & Anderson et al. (2009) \\
\hline & & Chilean coast & $2.7 \pm 0.8$ & & & 4 & Ochoa-acuña et al. (2002) \\
\hline & & Falkland Islands & $2.7 \pm 1.2$ & & & 30 & Thompson et al. (1993) \\
\hline \multirow[t]{2}{*}{ Thalassarche impavida } & $\begin{array}{l}\text { Campbell } \\
\text { albatross }\end{array}$ & New Zealand & $10.1 \pm 4.4$ & & & 35 & Thompson et al. (1993) \\
\hline & & & & & $124.6 \pm 74.6$ & 6 & Stewart et al. (1999) \\
\hline \multirow[t]{4}{*}{ Thalassarche chrysostoma } & Grey-headed & New Zealand & $6.9 \pm 2.4$ & & & 36 & Thompson et al. (1993) \\
\hline & albatross & South Georgia & $4.2 \pm 2.3$ & & & 34 & Thompson et al. (1993) \\
\hline & & & $8.9 \pm 2.9$ & & & 19 & Becker et al. (2002) \\
\hline & & & $9.5 \pm 2.8$ & $6.6 \pm 1.1$ & & 15 & Anderson et al. (2009) \\
\hline \multirow[t]{3}{*}{ Thalassarche steadi } & White-capped & New Zealand & $10.9 \pm 4.6$ & & & 20 & Thompson et al. (1993) \\
\hline & albatross & & & & $35.0 \pm 17.6$ & 42 & Stewart et al. (1999) \\
\hline & & $\begin{array}{l}\text { Southern Pacific and } \\
\text { Indian Oceans }\end{array}$ & & & $39.6 \pm 4.6$ & 29 & Hindell et al. (1999) \\
\hline \multirow[t]{2}{*}{ Phoebastria immutabilis } & Laysan albatross & Midway Atoll, Hawaii & $3.5 \pm 0.4$ & & & 13 & $\begin{array}{l}\text { Burger and Gochfeld } \\
(2000)\end{array}$ \\
\hline & & British Columbia, Canada & & & $11.9 \pm \mathrm{U}^{\mathrm{a}}$ & 11 & Elliott (2005) \\
\hline \multirow[t]{2}{*}{ Phoebastria nigripes } & Black-footed albatross & Midway Atoll, Hawaii & $19.6 \pm 1.8$ & & & 17 & $\begin{array}{l}\text { Burger and Gochfeld } \\
(2000)\end{array}$ \\
\hline & & British Columbia, Canada & & & $121 \pm \mathrm{U}^{\mathrm{a}}$ & 12 & Elliott (2005) \\
\hline
\end{tabular}

\footnotetext{
a $\mathrm{U}-$ unknown.
} 


\section{Results and discussion}

The observed levels in feathers and blood confirm that mercury concentrations in wandering albatrosses are much higher than those of several other albatrosses, including those from South Georgia (Table 1). Such high values have been attributed to the high rate of mercury intake from their upper trophic level diet combined with a slow moult cycle, biennial breeding and a physiological capability to demethylate mercury and sequester the inorganic form with selenium (Thompson et al., 1993; Stewart et al., 1999; Xavier et al., 2004). The low moult frequency is a contributing factor, but not the complete explanation as other albatrosses moult almost as infrequently (Weimerskirch, 1991; Prince et al., 1993). At South Georgia, wandering albatrosses tend to maintain a consistent feeding preference for fish and squid, whereas other albatrosses eat more lower trophic level prey such as Antarctic krill Euphausia superba during the austral summer (Xavier et al., 2003, 2004; Phillips et al., 2009, 2011).

Bioaccumulation of mercury with size has been documented in many species of fish (McArthur et al., 2003) and squid (Bustamante et al., 2006, 2008; Pierce et al., 2008; Pereira et al., 2009), which are the major components of albatross diets (Xavier et al., 2003). An estimated $86 \%$ of the mass of cephalopods consumed by wandering albatrosses is scavenged, and includes large species (Xavier and Croxall, 2007), and they also consume offal and discards from commercial fishing, which frequently consist of long-lived, largebodied demersal species (Xavier et al., 2004). Hence, wandering albatrosses are probably more likely than other albatross species to consume a greater proportion of large prey. Indeed, previous work has highlighted that variation in mercury burdens in seabirds often reflects differences in feeding strategies, including the relative importance of mesopelagic prey (Monteiro et al., 1998; Stewart et al., 1999; Becker et al., 2002; Anderson et al., 2009).

Mercury levels in feathers from wandering albatrosses ranging in age from chicks to mature adults showed no evidence of an overall linear trend ( $r=0.143, p=0.297$; Fig. 1$)$. This is consistent with a number of previous studies that tested in a similar way for correlations between mercury levels in tissues and bird age (Thompson et al., 1991, 1993; Becker et al., 2002). However, having the opportunity to sample young pre-breeders, we detected a surprisingly steep increase in mercury burden from the time of fledging to first return at the age of $4-6$ years. This was followed by a decline to a lower level by 9 years which was maintained
Table 2

Mercury concentration in feathers and chick down of the wandering albatross according to breeding status and sex (mean \pm SD and range, $\mathrm{mg} \mathrm{kg}^{-1}$ dry wt).

\begin{tabular}{lcclr}
\hline & $n$ & Mean value & SD & \multicolumn{1}{l}{ Range } \\
\hline $\begin{array}{l}\text { Chicks } \\
\text { Young pre-breeders }\end{array}$ & 8 & 6.14 & 1.91 & $4.25-9.91$ \\
$\begin{array}{l}\text { Males } \\
\text { Females }\end{array}$ & 2 & 45.81 & 4.28 & $42.78-48.84$ \\
$\begin{array}{l}\text { Pooled data } \\
\text { Old pre-breeders }\end{array}$ & 7 & 49.69 & 8.16 & $41.25-57.18$ \\
Males & 7 & 48.13 & 6.34 & $41.25-57.18$ \\
Females & 7 & 23.93 & & \\
Pooled data & 13 & 20.22 & 5.64 & $16.77-33.20$ \\
$\begin{array}{l}\text { Adults } \\
\text { Males }\end{array}$ & 21.20 & 8.10 & $10.89-25.46$ \\
Females & 16 & 18.90 & 6.32 & $10.89-33.20$ \\
Pooled data & 16 & 21.43 & & \\
& 34 & 20.14 & 8.41 & $8.09-36.58$ \\
& & & 7.64 & $8.09-39.82$ \\
\hline
\end{tabular}

thereafter in breeding adults. There were also significant differences in mercury concentrations in feathers of chicks ( $<1$ year), young pre-breeders ( $4-6$ years old), old pre-breeders ( $9-15$ years old) and breeding adults ( $11-33$ years old $)(F=51.62, p<0.001)$. Levels were lowest in chicks, intermediate in old pre-breeders and breeding adults, and greatest in young pre-breeders (Table 2). Repeatability in mercury concentration between the two feather samples taken from each individual $(n=55)$ was high, and significant $\left(F=5.08, p<0.0001, r_{\mathrm{i}}=0.804\right)$.

The higher mercury levels measured in the feathers of the young pre-breeders are probably linked to differences in moulting strategies. In breeding adults, as in most seabirds, moulting and breeding tend to be temporally segregated because both are energetically highly demanding (Bridge, 2006). Hence, albatrosses moult almost exclusively in the nonbreeding period, and must balance the extent of moult necessary to maintain flight efficiency and the demands of reproduction to the extent that in several species, birds may ultimately be forced to defer breeding in order to replace worn plumage (Langston and Rohwer, 1996). In wandering albatrosses, immature birds and individuals breeding for the first time possess fewer new feathers than experienced birds, which seems likely to reflect their greater difficulties in replacing feathers because of energy allocation constraints associated with their lower foraging skills (Weimerskirch, 1991). Since moult is a crucial mechanism for mercury excretion, this reduces the opportunities for pre-breeders and, it would appear from our results, particularly

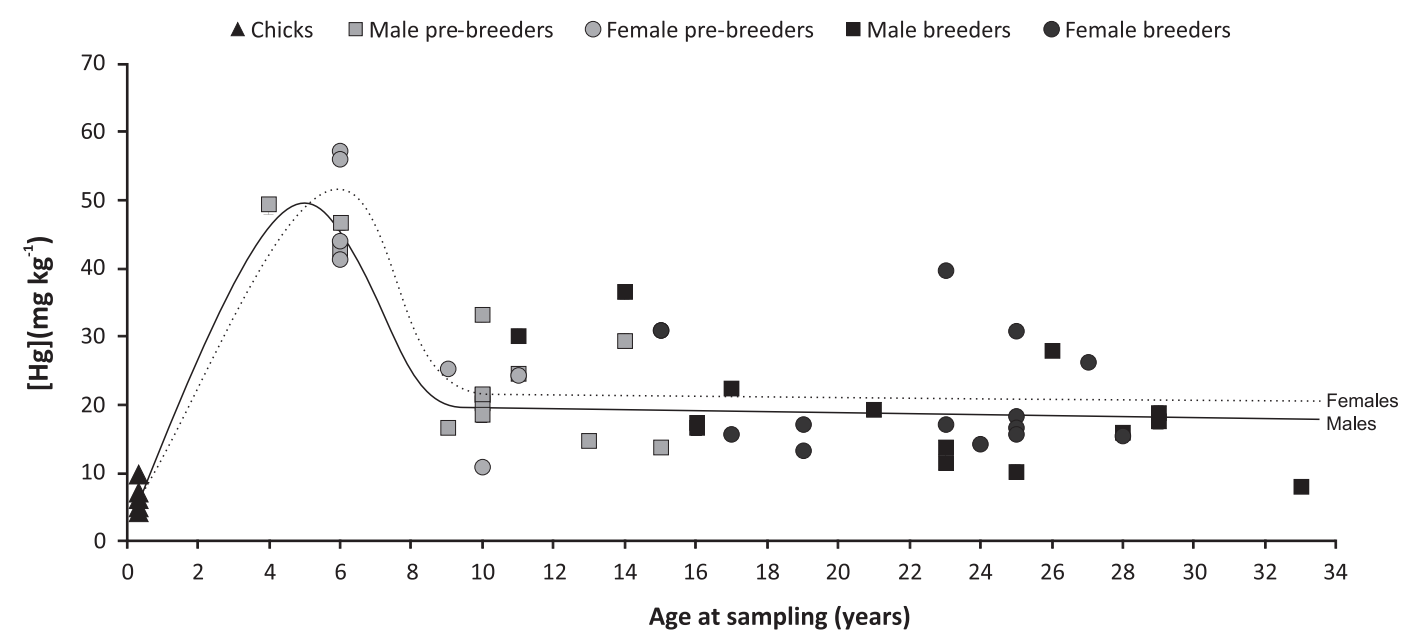

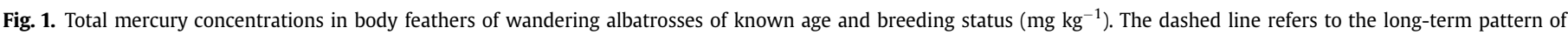
mercury accumulation in males and females. 

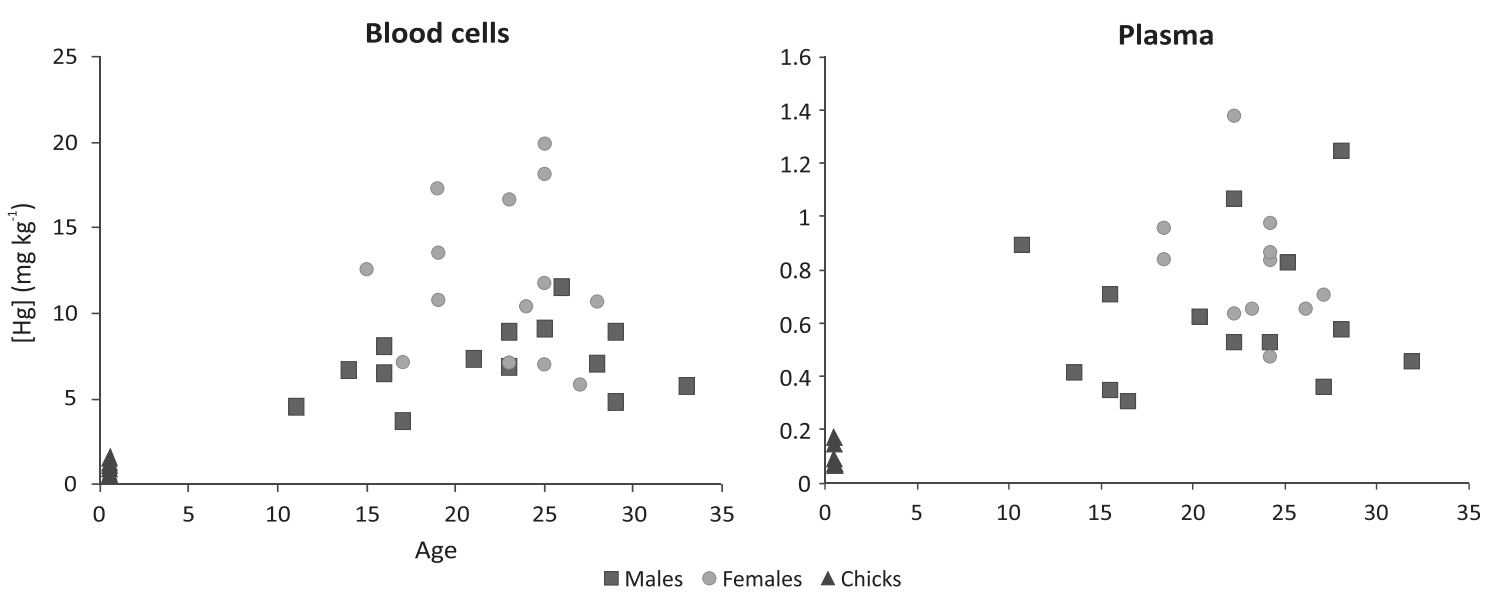

Fig. 2. Mercury levels in blood samples of albatrosses of known age ( $\mathrm{mg} \mathrm{kg}^{-1}$ ): (a) blood cells, (b) plasma.

the very youngest birds, to reduce their body pool of mercury by excretion into feathers.

Another factor contributing to differences in mercury concentrations in feathers of young pre-breeders compared with older wandering albatrosses could be variation in at-sea distribution or diet. The plumage of juvenile and immature wandering albatrosses is easily distinguished, and at sea observations in combination with recent tracking data indicate that young birds are more likely than adults to feed in subtropical or subantarctic waters, and that a significant proportion cross the Indian Ocean to wintering grounds around the southern and eastern coast of Australia (Weimerskirch et al., 2006).

Mercury concentrations in chick down were significantly lower than in feathers of pre-breeders or breeding adults probably

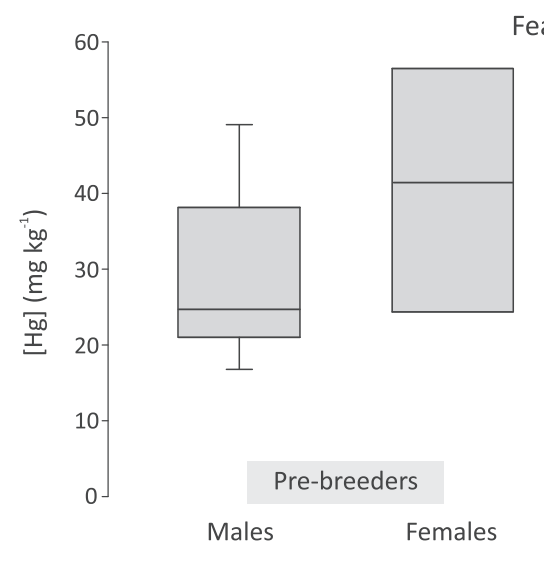

Feathers
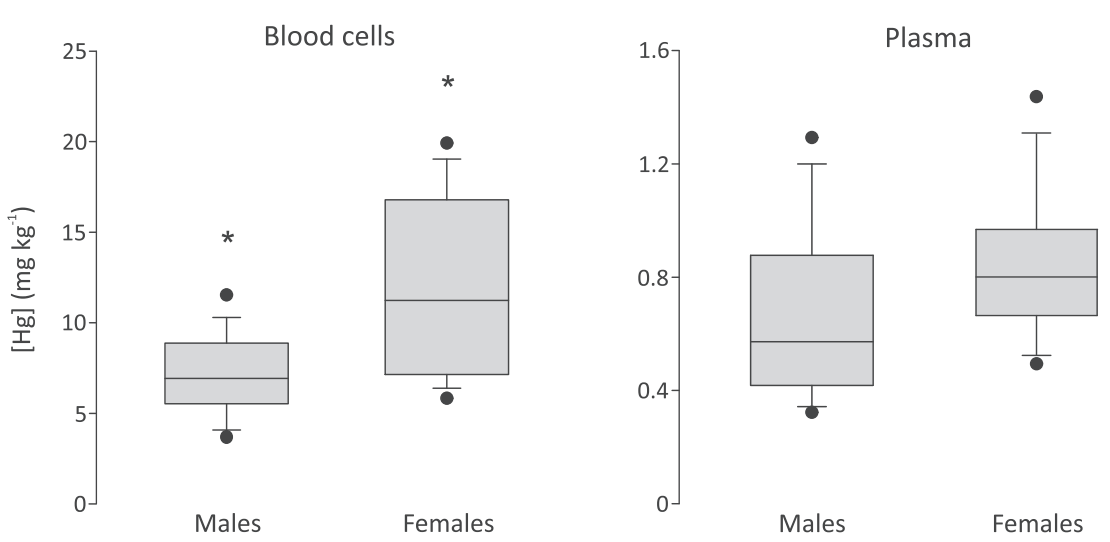

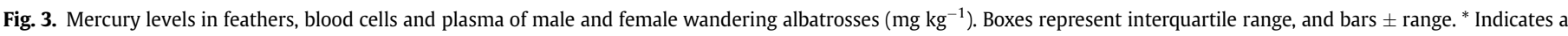
significant difference. 
because their exposure periods were short (chicks were only 1-6 months old when sampled), and also they were rapidly growing a complete set of plumage. The latter alone would tend to greatly dilute the levels of mercury excreted into new feathers, certainly by comparison with an older bird that might replace only half its plumage once every two years between breeding attempts.

Mercury concentrations in blood cells and plasma were significantly higher in breeding adults than chicks $(t=13.26, p<0.001$ and $t=10.05, p<0.001$, respectively). There was no significant linear correlation between mercury concentrations in either blood cells or plasma, and age in breeding adults $(r=0.107, p=0.589$ and $r=0.109, p=0.597$, respectively; Fig. 2 ). However, the pattern of mercury accumulation in the blood cells with age differed between sexes, with a higher rate of mercury accumulation in females than males (ANCOVA, age $F=0.445, p=0.511$; $\operatorname{sex} F=13.54, p=0.001$ ).

There was no effect of sex on mercury levels in feathers of young pre-breeders, old pre-breeders or breeding adults (Two-way ANOVA, effect of status $F=16.29, p<0.001$, effect of sex $F<0.001$, $p=0.985$, interaction $F=0.836, p=0.441$; Fig. 3). Nor was there an effect of sex on mercury levels in plasma of breeding adults $(t=1.893, p=0.185$; Table 3$)$. In contrast, mercury levels in blood cells were significantly higher in female than male breeders $(t=3.741, p<0.001$; Table 3; Fig. 3). Blood cells presumably reflect dietary mercury intake since the end of the moult, prior to the onset of the current breeding attempt. Those concentrations remain higher in females than males, suggesting they do not excrete sufficient quantities of mercury into the egg for this to have a substantial long-term effect. Instead, the difference suggests some sexual segregation in foraging areas or diet of breeding birds in the incubation or early to mid chick-rearing period, prior to sample collection. Male and female wandering albatrosses do show preferences for different water masses during breeding; males favour cold, Antarctic waters whereas females mostly use subantarctic and subtropical waters (Weimerskirch et al., 1993; Xavier et al., 2004; Xavier and Croxall, 2005). Moreover, in two years with differing environmental conditions, males consumed mainly fish (74\% by mass) whereas females consumed mainly cephalopods (67\%) (Xavier et al., 2004). However, differences in distribution or diet may be less pronounced during the nonbreeding season, given the lack of a sex effect on mercury levels in feathers. This accords with previous studies of stable isotope ratios; $\delta^{13} \mathrm{C}$ in feathers was higher in females than males, but there was no difference in $\delta{ }^{15} \mathrm{~N}$, indicating that females had a more northerly foraging habitat but did not feed at a higher trophic level during the nonbreeding period (Phillips et al., 2009; Ceia et al., 2012).

The high level of mercury contamination in the wandering albatross may constitute an additional stress in individuals within a species that is already facing conservation problems, mainly as a consequence of unsustainable incidental mortality associated with long-line fishing (Croxall et al., 1998; Nel et al., 2002; Xavier et al., 2004). Some degree of health surveillance, including contaminant monitoring, is advisable, as exposure to mercury may lead to deleterious effects (organ toxicity and reproductive or

\section{Table 3}

Mercury concentration in blood cells and plasma of the wandering albatross according to breeding status and sex (mean \pm SD and range, $\mathrm{mg} \mathrm{kg}^{-1}$ dry wt).

\begin{tabular}{|c|c|c|c|c|c|c|c|c|}
\hline & \multicolumn{4}{|c|}{ Blood cells } & \multicolumn{4}{|c|}{ Plasma } \\
\hline & $n$ & Mean & SD & Range & $n$ & Mean & SD & Range \\
\hline $\begin{array}{l}\text { Chicks } \\
\text { Adults }\end{array}$ & 7 & 0.84 & 0.36 & $0.42-1.40$ & 5 & 0.11 & 0.05 & $0.06-0.17$ \\
\hline Males & 14 & 7.10 & 2.10 & $3.69-11.53$ & 14 & 0.66 & 0.29 & $0.32-1.29$ \\
\hline Females & 14 & 12.04 & 4.55 & $5.83-19.91$ & 12 & 0.83 & 0.25 & $0.49-1.43$ \\
\hline Pooled data & 28 & 9.57 & 4.29 & 3.69-19.91 & 26 & 0.74 & 0.28 & $0.32-1.43$ \\
\hline
\end{tabular}

neurobehavioral impairment) (Scheuhammer, 1987). Mercury concentrations of over $0.5 \mathrm{mg} \mathrm{kg} \mathrm{mg}^{-1}$ in eggs and of over 9$20 \mathrm{mg} \mathrm{kg}^{-1}$ in feathers have been correlated with decreased reproductive success in some piscivorous birds (Scheuhammer, 1987; Burger and Gochfeld, 1997). Concentrations reported in this and other studies of wandering albatross are considerably higher, and so although marine birds are expected to have higher toxicity thresholds than terrestrial birds (Blévin et al., 2013), we cannot dismiss the possibility of adverse effects in this already threatened species.

\section{Acknowledgements}

This work was supported by the Portuguese Foundation for the Science and Technology (FCT) through a PhD grant to Sílvia Tavares (SFRH/BD/48908/2008),co-funded by the European Social Fund and Portuguese Government National Funds, and through the project POLAR. This paper represents a contribution to the British Antarctic Survey Ecosystems Programme, the national program PROPOLAR and the international programs of ICED and SCAR AnT-ERA.

\section{References}

Anderson, O.R.J., Phillips, R.A., McDonald, R.A., Shore, R.F., McGill, R.A.R., Bearhop, S., 2009. Influence of trophic position and foraging range on mercury levels within a seabird community. Marine Ecology Progress Series 375, 277-288.

Bearhop, S., Phillips, R.A., Thompson, D.R., Waldron, S., Furness, R.W., 2000. Mercury dynamics in great skuas Catharacta skua in relation to colony, diet and trophic status inferred from stable isotope signatures. Marine Ecology Progress Series 195, 261-268.

Becker, P.H., González-Solís, J., Behrends, B., Croxall, J., 2002. Feather mercury levels in seabirds at South Georgia: influence of trophic position, sex and age. Marine Ecology Progress Series 243, 261-269.

Blévin, P., Carravieri, A., Jaeger, A., Chastel, O., Bustamante, P., Cherel, Y., 2013. Wide range of contamination in chicks of Southern Ocean seabirds. PLoS One 8 (1), e54508.

Braune, B.M., Gaskin, D.E., 1987. Mercury levels in Bonaparte's gulls (Larus philadelphia) during autumn moult in the Quoddy region, New Brunswick, Canada. Archives of Environmental Contamination and Toxicology 16, 539-549.

Bridge, E.S., 2006. Influences of morphology and behaviour on wing-moult strategies in seabirds. Marine Ornithology 34, 7-19.

Burger, J., Gochfeld, M., 1997. Risk, mercury levels and birds: relating adverse laboratory effects to field biomonitoring. Environmental Research 75, 160-172.

Burger, J., Gochfeld, M., 2000. Metal levels in feathers of 12 species of seabirds from Midway Atoll in the northern Southern Pacific. Science of the Total Environment 257, 37-52.

Bustamante, P., Lahaye, V., Durnez, C., Churlaud, C., Caurant, F, 2006. Total and organic $\mathrm{Hg}$ concentrations in cephalopods from the North East Atlantic waters: influence of geographical origin and feeding ecology. Science of the Total Environment 368, 585-596.

Bustamante, P., González, A.F., Rocha, F., Miramand, P., Guerra, A., 2008. Metal and metalloid concentrations in the giant squid Architeuthis dux from Iberian waters. Marine Environmental Research 66, 278-287.

Ceia, F.R., Phillips, R.A., Ramos, J.A., Cherel, Y., Vieira, R.P., Richard, P., Xavier, J.C., 2012. Short- and long-term consistency in the foraging niche of wandering albatrosses. Marine Biology 159, 1581-1591.

Cossa, D., Heimbürger, L., Lannuzel, D., Rintoul, S.R., Butler, E.C.V., Bowie, A.R., Averty, B., Watson, R.J., Remenyi, T., 2011. Mercury in the Southern Ocean. Geochimica et Cosmochimica Acta 75, 4037-4052.

Croxall, J.P., Prince, P.A., Rothery, P., Wood, A.G., 1998. Population changes in albatrosses at South Georgia. In: Robertson, G., Gales, R. (Eds.), Albatross Biology and Conservation. Surrey Beatty and Sons, Chipping Norton, pp. 69-83.

Doi, R., Ohno, H., Harada, M., 1984. Mercury in feathers of wild birds from the mercury - polluted area along the shore of the Shiranui Sea, Japan. Science of the Total Environment 40 (1), 155-167.

Elliott, J.E., 2005. Trace metals, stable isotope ratios, and trophic relations in seabirds from the North Pacific Ocean. Environmental Toxicology and Chemistry 24 (12), 3099-3105.

EPA (United States), 2001. Mercury Update: Impact on Fish Advisories. EPA-823-F01-011. EPA, Washington.

Halpern, B.S., Walbridge, S., Selkoe, K.A., Kappel, C.V., Micheli, F., D’Agrosa, C., Bruno, J.F., Casey, K.S., Ebert, C., Fox, H.E., Fujita, R., Heinemann, D., Lenihan, H.S. Madin, E.M.P., Perry, M.T., Selig, E.R., Spalding, M., Steneck, R., Watson, R., 2008. A global map of human impact in ecosystems. Science 319, 948.

Hindell, M.A., Brothers, N., Gales, R., 1999. Mercury and cadmium concentrations in the tissues of three species of southern albatrosses. Polar Biology 22, 102-108.

Langston, N.E., Rohwer, S., 1996. Moult-breeding tradeoffs in albatrosses: life history implications for big birds. Oikos 76, 498-510. 
Lewis, S.A., Becker, P.H., Furness, R.W., 1993. Mercury levels in eggs, internal tissues and feathers of herring gulls Larus argentatus from the German Wadden Sea. Environmental Pollution 80, 293-299.

McArthur, T., Butler, E.C.V., Jackson, G.D., 2003. Mercury in the marine food chain in the Southern Ocean at Macquarie Island: an analysis of a top predator Patagonian toothfish (Dissostichus eleginoides) and a mid-trophic species the warty squid (Moroteuthis ingens). Polar Biology 27, 1-5.

Monteiro, L.R., Furness, R.W., 1995. Seabirds as monitors of mercury in the marine environment. Water Air and Soil Pollution 80, 851-870.

Monteiro, L.R., Granadeiro, J.P., Furness, R.W., 1998. Relationship between mercury levels and diet in Azores seabirds. Marine Ecology Progress Series 166, 259265.

Monteiro, L.R., Furness, R.W., 2001. Kinetics, dose-response, excretion, and toxicity of methylmercury in free-living Cory's Shearwaters chicks. Environmental Toxicology and Chemistry 20, 1816-1823.

Nel, D.C., Ryan, P.G., Nel, J.L., Klages, N.T.W., Wilson, R.P., Robertson, G., 2002 Foraging interactions of wandering albatrosses Diomedea exulans breeding on Marion Island with longline fisheries in the southern Indian Ocean. Ibis 144, 141-154.

Ochoa-acuña, H., Sepúlveda, M.S., Gross, T.S., 2002. Mercury in feathers from Chilean birds: influence of location, feeding strategy, and taxonomic affiliation. Marine Pollution Bulletin 44, 340-349.

Pereira, P., Raimundo, J., Vale, C., Kadar, E., 2009. Metal concentrations in digestive gland and mantle of Sepia officinalis from two coastal lagoons of Portugal. Science of the Total Environment 407, 1080-1088.

Phillips, R.A., Hamer, K.C., 2000. Postnatal development of northern fulmar chicks Fulmarus glacialis. Physiological and Biochemical Zoology 73, 597-604.

Phillips, R.A., Croxall, J.P., Silk, J.R.D., Briggs, D.R., 2008. Foraging ecology of albatrosses and petrels from South Georgia: two decades of insights from tracking technologies. Aquatic Conservation: Marine and Freshwater Ecosystems 17, S6S21.

Phillips, R.A., Bearhop, S., McGill, R.A.R., Dawson, D.A., 2009. Stable isotopes reveal individual variation in migration strategies and habitat preferences in a suite of seabirds during the non-breeding period. Oecologia 160 (4), 795-806.

Phillips, R.A., McGill, R.A.R., Dawson, D.A., Bearhop, S., 2011. Sexual segregation in distribution, diet and trophic level of seabirds: insights from stable isotope analysis. Marine Biology 158, 2199-2208.

Pierce, G.J., Stowasser, G., Haster, L.C., Bustamante, P., 2008. Geographic, seasonal and ontogenetic variation in cadmium and mercury concentrations in squid (Cephalopoda: Teuthoidea) from UK waters. Ecotoxicology and Environmental Safety 70, 422-432.

Prince, P.A., Rodwell, S., Jones, M., Rothery, P., 1993. Moult in black-browed and grey-headed albatrosses Diomedea melanophris and D. chrysostoma. Ibis 135, 121-131.
Ramos, R., González-Solís, J., 2012. Trace me if you can: the use of intrinsic biogeochemical markers in marine top predators. Frontiers in Ecology and the Environment 10 (5), 258-266.

Scheuhammer, A.M., 1987. The chronic toxicity of aluminium, cadmium, mercury, and lead in birds: a review. Environmental Pollution 46, 263-295.

Stewart, F.M., Phillips, R.A., Catry, P., Furness, R.W., 1997. Influence of species, age and diet on mercury concentrations in Shetland seabirds. Marine Ecology Progress Series 151, 237-244.

Stewart, F.M., Phillips, R.A., Bartle, J.A., Craig, J. Shooter, D., 1999. Influence of phylogeny, diet, moult schedule and sex on heavy metal concentrations in New Zealand Procellariiformes. Marine Ecology Progress Series 178, 295-305.

Streets, D., Zhang, Q., Wu, Y., 2009. Projections of global mercury emissions in 2050. Environmental Science \& Technology 43, 2983-2988.

Thompson, D.R., Furness, R.W., 1989. The chemical form of mercury stored in South Atlantic seabirds. Environmental Pollution 60, 305-317.

Thompson, D.R., Hamer, K.C., Furness, R.W., 1991. Mercury accumulation in Great Skuas Catharacta skua of known age and sex, and its effects upon breeding and survival. Journal of Applied Ecology 28 (2), 672-684.

Thompson, D.R., Furness, R.W., Lewis, S.A., 1993. Temporal and spatial variation in mercury concentrations in some albatrosses and petrels from the sub-Antarctic. Polar Biology 13, 239-244.

Tickell, W.L.N., 1968. The biology of the great albatrosses Diomedea exulans and Diomedea epomophora. Antarctic Research Series 12, 1-55.

Weimerskirch, H., 1991. Sex-specific differences in moult strategy in relation to breeding in the wandering albatross. The Condor 93, 731-737.

Weimerskirch, H., Salamolard, M., Sarrazin, F., Jouventin, P., 1993. Foraging strategy of wandering albatrosses through the breeding season: a study using satellite telemetry. The Auk 110, 325-342.

Weimerskirch, H., Akesson, S., Pinaud, D., 2006. Postnatal dispersal of wandering albatrosses Diomedea exulans: implications for the conservation of the species. Journal of Avian Biology 37, 23-28.

Xavier, J.C., Croxall, J.P., Trathan, P.N., Wood, A.G., 2003. Feeding strategies and diets of breeding grey-headed and wandering albatrosses at South Georgia. Marine Biology 143, 221-232.

Xavier, J.C., Trathan, P.N., Croxall, J.P., Wood, A.G., Podestá, G., Rodhouse, P.G., 2004 Foraging ecology and interactions with fisheries of wandering albatrosses (Diomedea exulans) breeding at South Georgia. Fisheries Oceanography 13 (5), 324-344.

Xavier, J.C., Croxall, J.P., 2005. Sexual differences in foraging behaviour and food choice: a case study of wandering albatrosses. In: Kruckstuhl, K., Neuhaus, P. (Eds.), Sexual Segregation in Vertebrates. Cambridge University Press, pp. 7491.

Xavier, J.C., Croxall, J.C., 2007. Predator-prey interactions: why do larger albatrosses eat bigger squid? Journal of Zoology 271 (4), 408-417. 